\section{Tuberculosis in Cyprus}

THe final report on investigations on tuberculosis in Cyprus, conducted by Dr. N. D. Bardswell for the National Association for the Prevention of Tuberculosis, has been issued (Tubercle, 20, 97, 165; 1939). An intensive study of the disease in the Larnaca district indicates that actually the incidence of pulmonary tuberculosis is low, 140 cases in a popula. tion of 42,000 , with an average death-rate of 0.69 per 1,000 population. There is little non-pulmonary, and no bovine, tuberculosis, and tho disease in distribution is sporadic and largely familial. These figures fall far short of estimates by the Cyprus authorities prior to the National Association's mission. The Cypriot has a high resistance to the disease, which appears to be transmitted to an unusual degree from one individual to another. This is dependent upon the national habits; families almost invariably live and sleep in one room, and, in winter, houses are always completely closed at night. The standard of living of the people is low and poverty almost universal, though the nutrition of the people appears to be adequate. Tuberculosis in the Larnaca district and in Cyprus generally, though low in incidence and benign in type, is difficult to control owing to the general conditions existing in the island. The most effective measures would bo the establishment of dispensaries in various parts of the island, and of a small sanatorium for education and treatment of the more favourable cases. A comprehensive tuberculosis scheme on these lines is in process of organization.

\section{The Government Laboratory}

Reponting on the work of the Government Iuboratory for the year ending Narch 31, 1939, the Government Chemist, Dr. J. J. Fox, surveys the scientific work which is carried on at the laboratory in Clement's Inn Passage, at the Custom House, London, at the chemical stations at certain seaports, at the Geological Survey Museum, at the Office of Works Stores, and at the War Office Supply Reserve Depot, Deptford. Substantially moro than half a million examples were dealt with, although the number was about seren thousand less than in the preceding year. As is well known, these samples are drawn from an extremely wide range of products; foodstuffs and medicinal substances are tested for purity and for conformity with specification, beverages, oils, etc., are assessed for duty, metals, coal, rubber, cement and many other materials purchased by Government Departments aro submitted to examination, and expert assistance is rendered in the detection of fraud. In addition, the Government Laboratory makes a very substantial direct addition to chemical science as a result of the iinisiy investigations which its normal work necessitates, of its participation in international oceanic research, of the pure research work which is con. stantly in hand, and of the personal contributions of members of the staff to the deliberations of various councils and committees which deal with scientific and industrial problems.

\section{Farm Electrification}

TrE recent trends in research and development which characterize farming to-day are discussed in an articlo contributed to the Electrical Review of September 15 by A. G. H. Dent. The types of farming in Great Britain are now very varied; there are few large fields of wheat and barley; but the average farm produces dairy produce, poultry, market gardening and livestock and a certain amount of grain for consumption by the livestock. The electrical authorities giving a supply to some areas have little difficulty in showing farmers that they can get an economic return by using electricity, but in other areas the problem is a difficult one. The cost of giving facilities to a farm at some distance from the supply may be high, and there may be little evidence of an annual return which would justify the authorities in giving these facilities. Notwithstanding drawbacks, the development of rural electrical supply in Great Britain has reached a position comparable with that in any other country. We are glad that the British Electrical and Allied Industries Research Association is now examining the standardization problem of supply to isolated farms and is putting into action schemes of experiment and research applied to various farm processes. These schemes cover both agricultural and horticultural experimental work. The plans of research aro both technical and economic in character. They aim at establishing the best and most practical technique of doing a farming operation, the most suitable apparatus for the job and the proper method of application. On the economic side, the aim is to find the exact cost of the electrical method in com. parison with other methods and to find out what modifications of practice are desirable to obtain the maximum efficiency from the electrical method.

\section{Science and Fruit Growing}

Recent issues of the American Fruit Grouer. contain several brief announcements of successful applications of science to the fruit-growing industry. The issue for May describes the use of solidified carbon dioxide in addition to the usual wet ice for the cooling of strawberries during transit from Louisiana to New York. The new method saves 25-40 per cent in refrigeration costs, and has the additional advantage that the gas resulting from evaporation enhances the keeping quality of the fruit. Prof. MI. A. Blake of the New Jersey Experi. ment Station shows, in the same issue, that stout vegetative growth of the apple shoot is more to be desired for fruit bud production than long slender shoots. The formation of such buds depends upon the presence in the wood of more starch and sugars than are utilized in growth and respiration. This excess cannot be stored while succulent or rapid growth continues, but only after growth in length is arrested. R. J. Cohen, in another direction, has used the oil from grapefruit seeds as a mordant in textile dyeing, whilst Dr. WV. M. Neal has tested the residue from such seeds as a possible food for livestock. The 
July number contains a brief account of the investigations of Dr. E. N. Cory of Maryland into the insect pests of chestnut, hazel nut and walnut trees. A now departure in control practico lies in the use of synthetic cryolite and barium fluosilicate, applied as a spray or dust against the walnut husk maggot. A fascinating study of codling moth damage has been made by John A. Callenbach of Wisconsin University. He found that such injury was greatest near dusty roads. Dust upon the fruit provented tho proper covering of spray fluids, and it has been shown that roads can be rendered dustless by the uso of calcium chlorido spread upon the surface.

\section{Check-Lists of Forest Trees in Ceylon}

THE Imperial Forestry Institute at Oxford has been issuing a series of check-lists of the forest trees and shrubs of the British Empire, under the editorship of Dr. J. Burtt Davy and Mr. A. C. Hoyle. The fourth of the series is entitled "Draft of First Description Check-List for Ceylon". Theso monographs aro chiefly designed for the use of forest officers. So far, although there has been a forestry clepartment in Ceylon for moro than half a century, all the forest officer has had to consult is Trimen's "Handbook of the Flora of Ceylon", consisting of six large tomes, published some thirty-fivo years ago, with a supplement by Alaton issued in 1931. The Check-List in question has been compiled from published records and herbarium material. Some 832 species of trees and shrubs aro included. In addition, a list of exotic conifers introduced into Ceylon, comprising twenty-fivo species (genera, Callitris, Cupressus, Juniperus, Widdringtonia, Abies, Picea, Pinus, Pseudotsuga, Sequoia, Taxodium, 'Tsuga), is included in an appendix. There is also an indispensable list of vernacular names.

\section{Science Progress}

Tue editors and publishers (Messrs. Edward Frnold and Co.) of Science Progress, founded by Sir Ronald Ross in 1907, announce with regret that the October number will bo the last to appear for tho present. The purpose of this well-known quarterly review is to record recent advances in pure science and to publish articles by those who have played a leading part in such work; as research of this lind is bound to be seriously diminished in war-time, it has been reluctantly decided to suspend publication until conditions are more favourable.

\section{The Faraday Society}

TuE Faraday Society will continue its normal activities so far as possible during the war. Roughly 60 per cent of the members are normally resident in the United Kingdom, and 40 per cent overseas, including 8 per cent resident in German territories. The Society's services to its members consist mainly in the regular publication of the Transactions and in the provision twice yearly of meetings of such importance that it is worth while coming from all parts of the world to attend. This latter activity must obviously be suspended for the time being, but it may be possible to organize 'general discussion' in writing, and to publish the final record. The papers which were to have been dis. cussed in Cambridge during September 25-27 will be published early in 1940, and it can then bo seen whether a written 'discussion' is practicable and useful. The Transactions will appear regularly every month and the policy of publishing all papers as soon as they have been refereed and accepted will bo continued. It is hoped, moreover, that the flow of papers from overseas will continue to increase. It should bo emphasized that, though the Transactions are printed in English, the Society will, if desired, bear the cost of translating any accepted paper which may be written in another language. The usual arrangements for exchange of membership with the Electrochemical Society, the Nederlandsche Chemische Vereeniging and the Société de Chimio Physiquo will be continued for 1940.

\section{Institution of Electrical Engineers}

IT has been decided by the Council that as many as possible of the activities of the Institution of Electrical Engineers should be carried on during the period of the war in the sams way as hitherto, and that the library and headquarters of the Institution should remain for the time being in the present building at Savoy Place, W.C.2. All meetings that wero to have been held in Isondon for the reading and discussion of papers have been cancelled. Most of the local centres have also suspended their pro. grammes. As an alternative to meetings, a complete list of the papers that were to have been read will be issued to members at the end of October, and advance copies can be obtained on application to the Secretary. Copies of tho presidential address, which was to have been delivered by Mr. Johnstono Wright at the opening meeting in London on October 26, will bo circulated. As already announced, the associate membership examination arranged for November next will take place, and it is hoped that it will bo found practicablo to continue to hold this examination at the usual intervals in future.

\section{The Linnean Society}

TrE Linnean Society of London has decided to carry on its functions at Burlington House, London, during the war, so far as is possible. Tha rooms of the Society will be open from 10 a.m. until half an hour before sunset. Three meetings have been arranged to be held before Christmas, on October 26, November 9 and 23, beginning at 2.30 p.m. The Council of the Society is particularly anxious that the rooms of the Society shall be maintained as a central meeting place for biologists for the purpose of both formal and informal discussions.

\section{British Psychologica! Society}

Tine work of the British Psychological Society is being carried on at 20 IVest Avenue, Hendon, London, N.W.4, where correspondence and inquiries 